\title{
The Determinants of Capital Structure: Evidence from Albania
}

\section{Anila Çekrezi}

\author{
Department of Finance and Accounting, \\ University "A.Xhuvani”, Elbasan, Albania \\ Email: vocianila@yahoo.com
}

Doi:10.5901/ajis.2013.v2n9p370

\begin{abstract}
This paper attempts to explore the impact of firm specific factors and macroeconomic factors on capital structure decision for a sample of 53 non- listed firms, which operate in Albania, over the period 2008-2011. In this paper is used total debt to total assets (TDTA) as dependent variable and nine independent variables: tangibility (TANG), liquidity (LIQ), profitability (ROA , size (SIZE), business risk(RISK), non-debt tax shields (NDTSH), GDP growth rate(GDP), inflation rate (INF) and interest rate (INT). The investigation uses cross-sectional time series data which are collected from the Balance Sheet Annual Reports, the official document delivered to the State Tax Office. This study found that tangibility (the ratio of fixed assets to total assets), liquidity (the ratio of current assets to current liabilities), profitability (the ratio of earnings after taxes to total assets), size (natural logarithm of total assets) and risk (the ratio of standard deviation of sales to average value of sales) have a significant impact on leverage. Also it is found that NDTSH has a negative but not significant relation with leverage and GDP growth rate, inflation and interest rate have a positive but not a significant relation with leverage.
\end{abstract}

Keywords: Albania, Capital structure; Firm's Specific Factors, Country Factors, Leverage.

\section{Introduction}

Many researchers have conducted studies to prove the evidence of the theories of capital structure, but it still remains one of the most discussed issue in modern corporate finance. "How do firms choose their capital structure"? (Myers, 1984 , p. 575) still remains a question that needs an answer. For this reason other empirical studies on this issue are done and will be done in order to bring further evidence on the capital structure theories. Myers (1984) study is one of the most cited among the vast literature on capital structure, which explained corporate financing through taking in consideration some of the firm specific factors in the developed countries. This study examines firm specific factors and macroeconomic factors that were not taken in consideration by Myers' (1984) model.

Many studies are focused on researches about the determinants of the of debt choice (Titman and Wessels, 1988, Harris and Raviv, 1991, Rajan and Zingales, 1995), finding different evidence in their results. This differences are of two types (1) the signs of the regression coefficients estimated from the authors are different, (2) the statistical significance of the regression coefficient vary from one study to another one.

Results from developing countries: Titman and Wessels (1988) study in USA found that asset tangibility, non-debt tax shields, financial distress (volatility) and growth do not affect leverage; and leverage (short-term measure) negatively related to firm size. Harris and Raviv (1991) study concluded that leverage increases with fixed assets tangibility, nondebt tax shields, firm size and growth opportunities and decreases with financial distress (volatility) and profitability. According to DeAngelo and Masulis (1980), non-debt tax shields can serve as an alternative to debt tax shield. Non debt tax shields are created by depreciation expenses which are tax deductible but do not require any cash outlay. As existence of high non-debt tax shields has already reduced tax burden, a firm will require less amount of debt to reduce its total tax liability and the relation between leverage and non-debt tax shield is negative.

Macroeconomic variables are also very important on capital structure decision, which are recently introduced in the studies of different scholars. These factors are mostly studied in the developed counties (Mateus, 2006; Frank and Goyal, 2007) and only a few studies are conducted in the developing countries (Mutenheri and Green, 2002; Paydar and Bardai, 2012) study in Malaysia). Studying macroeconomic variables like GDP growth, inflation rate and interest rate in the Albania economic contest will be more interesting.

This study is focused on providing empirical evidence on the relationship between firm's specific factors (tangibility, liquidity, profitability, size, risk and non-debt tax shields) and macroeconomic factors (GDP growth rate, inflation rate and interest rate) on the capital structure choice among debt and equity, of non-traded small firms in Albania. The data has 
been retrieved from the Annual Reports submitted by the firms to the State Tax Office. A sample of 53 firms over a four year period, 2008-2011, is used in the analysis and in lack of an active stock market we have taken only accounting measures to estimate the capital structure of each firm.

The rest of this paper is organized as follows: the next section is literature review on the issue discussed; the third section describes the data, variable definition and regression model; the fourth section is hypothesis development of this study. The last section summarizes descriptive statistics and the regression results.

\section{Literature review}

Different authors have studied the firm's specific factors which influence on capital structure choice of the companies. So, previous studies by Titman and Wessels (1988), Rajan and Zingales (1995) argue that the ratio of fixed assets to total assets (tangibility) should be an important factor for leverage. In the recent studies, liquidity is also considered significantly affecting the capital structure choice of firms (Opler et al., 1999; Antoniou et al., 2002; Anderson, 2002). Also studies done in different countries have proved the negative relationship between liquidity and capital structure (Opler et al., 1999; Antoniou et al., 2002; Shahjahanpour et al., 2010) supporting the static trade-off model. Among the studies evidenced the negative relationship between profitability and leverage were those of Titman and Wessels (1988), Rajan and Zingales (1995), Antoniou et al. (2002), Daskalakis and Psillaki (2006), Degryse et al. (2009) and Frank and Goyal (2009) supporting the pecking order theory. A number of empirical studies have concluded that leverage ratios may be related to firm size: Titman and Wessels (1988), Rajan and Zingales (1995), Frank and Goyal (2003), Daskalakis and Psillaki (2006), Frank and Goyal (2009).

The cost of financial distress can be increased by risk, while the tax shield can be reduced. According to the tradeoff theory, when the volatility of earnings is high, firms should use less debt. A higher operating risk combined with higher financing risks will result in higher probability of bankruptcy (Myers, 1984). At the other side DeAngelo and Masulis (1980) argue that the marginal corporate savings from an additional unit of debt decreases with increasing non-debt tax shields.

Results on the effect of macroeconomic variables on capital structure choice are different. GDP growth rate is proved to have a positive relation in the study of Bas et al. (2009) and a negative relation in the studies of Gurcharan (2010) and Dincergok and Yalciner (2011).

The inflation rates were reported negatively affecting capital structure choice by Gulati and Zantout (1997), Mateus (2006) and Bas et al. (2009). However, positive association between the two variables is found by Concorou (1977), but in Mutenheri and Green (2002) study no significant relationship is found.

The third macroeconomic variable examined in this study is the interest rate, which is found negative related to capital structure in the studies of Antoniou et al. (2002) and Dincergok and Yalciner (2011), but positive related in the study of Bas et al. (2009). These macroeconomics factors need to be examined in the Albanian economic environment.

Many empirical studies had been conducted in order to examine the above mentioned factors on different countries and in different contests. In prior studies are used different measurements for capital structure (leverage) and using proxies for the determinants of leverage (firm's specific factors and macroeconomic factors). The problem is that there are no studies conducted in Albania (very few in Macedonia) and this study attempts to study this issue in the Albanian contest.

\section{Research Methodology}

In this section, we describe our sample, variables and the model used in determining the impact of the independent variables on firm's capital structure.

\subsection{Data and Variables Definitions}

The sample used is of 53 non-traded firms covering the period 2008-2011. All firms can be classified as SME and based on Strategic Plan for the Development of SME-s 2007-2013(Ministry of Energy, Transport and Economy of Albania 2007), these firms contributes with about 60 percent of the employment in the private sector. All the data are collected from the Balance Sheet Annual Reports, the official document delivered to the State Tax Office.

The independent variables used in the analysis are:

ROA (Return on asset) $=$ Earnings after taxes /Total asset

TANG (Tangibility) =Net fixed assets/Total assets

SIZE=Natural logarithm of total assets 


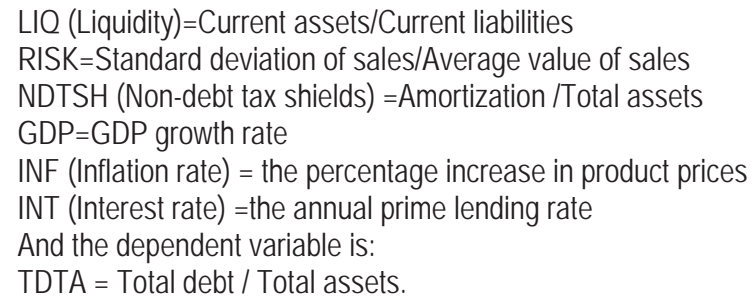

\subsection{The Model}

We use a simple multiple regression analysis to test TDTA as the dependent variable against the above mentioned independent variables. The model used in our study is as follows:

Ytdta $=\alpha+\alpha 1 *$ TANG $+\alpha 2 * L I Q+\alpha 3 * R O A+\alpha 4 * S I Z E+$

$\alpha 5 * R I S K+\alpha 6 * N D T S H+\alpha 7 * G D P+\alpha 8 * I N F+\alpha * I N T+\varepsilon$

Where Ytdta indicates firm's leverage which will be measured through total debt ratio for the firms in sample and $\varepsilon$ is the error terms. Using data as described earlier we will estimate all coefficients (alphas) of the equation.

\section{Hypotheses development}

In order to identify the effect the selected determinants on the firm's capital structure decision and the effect of industry the study used nine hypotheses which are presented below:

\section{$4.1 \mathrm{H}$ 1: Asset tangibility is positively related to capital structure decision.}

The lower expected costs of distress and fewer debt-related agency problems predict a positive relation between tangibility and leverage (Frank \& Goyal, 2009). The pecking order theory makes opposite predictions. Low information asymmetry associated with tangible assets makes equity issuances less costly. Thus, leverage ratios should be lower for firms with higher tangibility (Frank \& Goyal, 2009).

\subsection{H 2: Liquidity is negatively related to capital structure decision.}

The relationship between cash holdings (liquidity) and leverage is not clearly determined under the trade-off model (Saddour, 2006).According to pecking order theory liquidity has a negative relation with leverage. If amount of money needed for investment are higher than retained earnings, firms should issue new debt. "Thus, leverage increases whereas cash holdings fall. However, when investment needs are less than retained earnings, firms repay their debt and accumulate cash" (Saddour, 2006).

\subsection{H 3: Profitability is negatively related to capital structure decision.}

Trade off-theory suggest that profitable firms face lower expected costs of financial distress and find interest tax shields more valuable. Thus, the tax and the bankruptcy costs perspective predicts that profitable firms use more debt( Frank and Goyal ,2009).Regarding book leverage, the trade-off theory predicts that it should be positively correlated with expected profitability because higher expected profitability corresponds to higher benefits of debt and lower costs of financial distress. Such a relation will be observed empirically if the costs of adjusting leverage are relatively low and adjustments occur relatively quickly. For market leverage, the tradeoff theory does not have a definite prediction since firm value also increases with expected profitability (Xu, 2012).

\subsection{H 4: The size of the company is positively related to capital structure decision.}

Large, more diversified, firms face lower default risk. Thus, the trade-off theory predicts larger, more mature firms to have relatively more debt (Frank and Goyal, 2009). Large firms have had an opportunity to retain earnings (Frank \& Goyal, 2009).This means that they should decrease firm's debt. 


\subsection{H 5: Risk is negatively related to capital structure decision.}

The cost of financial distress can be increased by risk, while the tax shield can be reduced. According to the trade-off theory, when the volatility of earnings is high, firms should use less debt. A higher operating risk combined with higher financing risks will result in higher probability of bankruptcy (Myers, 1984). A complicated version of the pecking order theory states that if a firm does not want to pass up profitable projects in the future, then it should use less debt at present. Therefore, a negative relationship between leverage and the firm risk is expected.

Titman and Wessels (1988) study found a negative relationship between risk and leverage but Paydar and Bardai (2012) study in Malaysia on manufacturing companies during a seven-year period from 2004 to 2010 ,found no significant relationship among the determinants of capital structure and risk ( the ratio of sales over operating income) .

\subsection{H 6: Non-debt tax shields are negatively related to capital structure decision.}

Firms can use non-debt tax shields such as depreciation to reduce corporate tax. Thus, a higher non-debt tax shield reduces the potential tax benefit of debt and hence it should be inversely related to leverage. But such relation can change if the marginal tax rate expected from the interest tax shield is higher (Dincergok and Yalciner, 2011).

\subsection{H 7: GDP growth rate is positively related to capital structure decision.}

Several studies have provided empirical evidence on a positive relationship between GDP growth and leverage (Mateus, 2006; Saledi and Manesh, 2012). Mateus (2006) investigates the capital structure choices for a sample of 19,752 unlisted Western European firms for the period 1994- 2004. He found that the coefficient of the GDP growth rate is positive but not statistically significant.

\subsection{H 8: Inflation rate is negatively related to capital structure decision.}

Inflation management is one of the hardest tasks an economic policymaker has to undertake .It was one of the macroeconomics factors analyzed by different empirical studies in order to identify the relationship between this variable and leverage (Concorou ,1977; Gulati and Zantout ,1997; Mutenheri and Green ,2002; Mateus ,2006 ; Gurcharan ,2010). Concorou (1977) study indicated that inflation is positively related to leverage, but other researchers found that the influence of inflation on capital structure is insignificant (Mutenhei and Green, 2002; Gurcharan, 2010).

\subsection{H 9: Interest rate is negatively related to capital structure decision.}

Pecking order theory suggest that firms will choose the cheapest source of financing the activities. In the case of the static trade-off theory, firms choose finance so that the marginal costs across financing sources are all equal. According to Antoniou et al. (2002) and Dincergok and Yalciner(2011), the interest rate is negatively related to leverage.

\section{Empirical Results}

\subsection{Descriptive Statistics}

The tables below present the correlation coefficients between the dependent variables and the independent ones.

Table 1: Correlation coefficients, using the observations 1:1 - 53:4, 5\% critical value (two-tailed) $=0.1348$ for $n=212$

\begin{tabular}{|c|c|c|c|c|c|c|c|c|c|c|}
\hline Ytdta & TANG & LIQ & ROA & SIZE & RISK & NDTSH & GDP & INF & INT & \\
\hline 1.0000 & 0.2145 & 0.0515 & -0.4835 & 0.2207 & 0.2230 & -0.0078 & 0.1639 & -0.0285 & 0.0856 & Ytdta \\
\hline & 1.0000 & 0.0848 & -0.2553 & -0.1085 & 0.2404 & 0.2768 & 0.0232 & 0.0058 & 0.0017 & TANG \\
\hline & & 1.0000 & -0.0181 & -0.0817 & -0.0155 & -0.0205 & -0.0815 & 0.0406 & -0.0671 & LIQ \\
\hline & & & 1.0000 & -0.2386 & -0.2642 & 0.0187 & 0.0362 & -0.0805 & 0.0975 & ROA \\
\hline & & & & 1.0000 & 0.0758 & 0.0681 & -0.1065 & 0.0385 & -0.0760 & SIZE \\
\hline & & & & & 1.0000 & 0.2265 & -0.0414 & -0.0094 & -0.0040 & RISK \\
\hline & & & & & & 1.0000 & -0.0765 & -0.0584 & 0.0308 & NDTSH \\
\hline
\end{tabular}




\begin{tabular}{|c|c|l|l|l|l|l|l|l|l|l|}
\hline & & & & & & & 1.0000 & 0.2329 & 0.1073 & GDP \\
\hline & & & & & & & & 1.0000 & -0.9390 & INT \\
\hline & & & & & & & & & 1.0000 & INF \\
\hline
\end{tabular}

Table 1 shows the correlation between the explanatory variables specifically with respect to TDTA. As we can notice TDTA is positively correlated with TANG (21.45 percent), LIQ (5.15 percent), SIZE (22.07 percent), RISK (22.30 percent), GDP (16.39 percent) and INT (8.56 percent). Also it is demonstrated that TDTA is negatively correlated with ROA (48.35 percent) and has a weak negative correlation with NDTSH ( 0.78 percent) and INF (2.85 percent).

Table 2: Summary Statistics, using the observations 1:1 - 53:4

\begin{tabular}{|c|c|c|c|c|c|c|c|c|}
\hline Variable & Mean & Median & Minimum & Maximum & Std. Dev. & C.V. & Skewness & Ex.kurtosis \\
\hline Ytdta & 0.5875 & 0.6334 & 0.0188 & 0.9807 & 0.261631 & 0.4453 & -0.6067 & -0.7429 \\
\hline TANG & 0.2570 & 0.1548 & 0.0000 & 0.9399 & 0.2709 & 1.0539 & 1.1395 & 0.1550 \\
\hline LIQ & 10.7378 & 1.8266 & 0.0829 & 298.601 & 32.5597 & 3.0323 & 6.0382 & 42.3760 \\
\hline ROA & 0.0885 & 0.0607 & 0.0010 & 0.6913 & 0.0921 & 1.0410 & 2.7315 & 10.7403 \\
\hline SIZE & 17.6074 & 17.5791 & 14.5250 & 20.3677 & 1.2532 & 0.0712 & 0.1160 & -0.6123 \\
\hline RISK & 0.3409 & 0.2990 & 0.0619 & 1.4275 & 0.2564 & 0.7523 & 1.8276 & 4.6806 \\
\hline NDTSH & 0.0198 & 0.0075 & 0.0000 & 0.3952 & 0.0415 & 2.0923 & 6.4635 & 52.3498 \\
\hline GDP & 0.0436 & 0.0361 & 0.0272 & 0.0750 & 0.0187 & 0.4284 & 0.9817 & -0.7976 \\
\hline INF & 0.0320 & 0.0345 & 0.0230 & 0.0360 & 0.0053 & 0.1643 & -1.0922 & -0.7144 \\
\hline INT & 0.1167 & 0.1152 & 0.1117 & 0.1246 & 0.0051 & 0.04349 & 0.6195 & -1.1870 \\
\hline
\end{tabular}

Notes: TDTA = total debt to total assets; TANG=net fixed assets to total assets; LIQ=current assets to current liabilities; ROE = return on equity; SIZE=natural logarithm of assets; RISK= standard deviation of sales to average value of sales; NDTSH= amortization to total assets; GDP= growth rate of gross domestic product; INF= the percentage increase of product's prices; INT=prime lending rate.

Table 2 reports summary statistics for the variables used in our study. It shows that the average total debt to total asset ratio (TDTA) for the sample as a whole is 0.5875 .

\subsection{Multicollinearity Analysis of the Variables}

It is possible that the selected variables may be correlated, so the chosen variables may actually measure the effects of several different variables. To address this problem the study tests for the multicollinearity. The Variance Inflation Factor (VIF) is a commonly used for testing the multicollinearity problems. It shows the degree to which each independent variable is explained by other independent variable. As a rule of thumb, a VIF greater than 10 indicates the presence of harmful collinearity (Gujarati, 2003).

Table 3: Multicollinearity analysis of the variables selected

\begin{tabular}{|c|c|c|c|c|c|}
\hline Variable & VIF(1) & Variable & VIF(2) & Variable & VIF(3) \\
\hline TANG & 1.255 & TANG & 1.255 & TANG & 1.255 \\
LIQ & 1.030 & LIQ & 1.029 & LIQ & 1.028 \\
ROA & 1.250 & ROA & 1.247 & ROA & 1.248 \\
SIZE & 1.135 & SIZE & 1.135 & SIZE & 1.135 \\
RISK & 1.162 & RISK & 1.161 & RISK & 1.161 \\
NDTSH & 1.168 & NDTSH & 1.166 & NDTSH & 1.166 \\
GDP & 21.415 & GDP & 1.092 & GDP & 1.038 \\
INF & 178.716 & INF & 1.075 & INT & 1.029 \\
INT & 170.983 & & & & \\
\hline
\end{tabular}

Table 3 shows the Variance Inflation Factor (VIF) of all the variables of this study. As we can see from the results the VIF (1) of GDP is equal to 21.415 , of INF 178.716 and of INT is 170.983 . So, it indicates the presence of a harmful collinearity among the variables this three variables which should not be used together in the same model. The results of VIF (2) and 
VIF (3) show that VIF for all the variables are less than 10 and the problem of multicollinearity is resolved by eliminating one of the variables (INF or INT) from the model.

\subsection{The Research Results}

Employing panel data (cross pooled sectional data) analysis (Gujarati, 2004) and using Gretl (2012) statistical package we obtain the following output of regressions:

Table 4: Summery of models.

\begin{tabular}{|c|c|c|c|c|c|}
\hline Variables & $\begin{array}{c}\text { Model } 1 \\
(\text { WLS) }\end{array}$ & $\begin{array}{c}\text { Model } 2 \\
(\text { WLS) }\end{array}$ & $\begin{array}{c}\text { Model } 3 \\
(\text { WLS) }\end{array}$ & $\begin{array}{c}\text { Model } 4 \\
\text { (WLS) }\end{array}$ & $\begin{array}{c}\text { Model } 5 \\
\text { (WLS) }\end{array}$ \\
\hline Independent & Ytdta & Ytdta & Ytdta & Ytdta & Ytdta \\
\hline Constant & 0.0024 & -0.0798 & 0.0426 & $-0.8564^{\star \star \star}$ & -4.1665 \\
\hline TANG & $0.1276^{* \star *}$ & $0.1629 * \star \star$ & $0.1395^{\star \star \star}$ & $0.1379 * \star \star$ & $0.1333^{\star \star \star}$ \\
\hline LIQ & - & 0.0003 & $0.0005^{\star}$ & $0.0005^{*}$ & $0.0004^{*}$ \\
\hline $\mathrm{ROA}$ & $-1.2169 * \star \star$ & $-1.1685^{\star \star \star}$ & $-1.2402^{\star \star \star}$ & $-1.2402^{\star \star \star}$ & $-1.2456^{\star \star \star}$ \\
\hline SIZE & $0.0368^{* \star *}$ & $0.0409 * \star \star$ & 0.0359 *** & $0.0354^{\star \star \star}$ & $0.0350^{\star \star \star}$ \\
\hline RISK & $0.0992^{*}$ & $0.1128^{\star \star}$ & $0.1140^{\star \star}$ & $0.1142^{\star *}$ & $0.1193^{\star \star}$ \\
\hline NDTSH & - & -0.5775 & -0.5140 & -0.5125 & -0.5142 \\
\hline GDP & - & - & $3.7768^{\star \star *}$ & $3.1977^{\star \star \star}$ & 1.0303 \\
\hline INF & - & - & $-6.0884^{\star \star \star}$ & - & 22.7398 \\
\hline INT & - & - & - & $6.3173^{\star \star \star}$ & 29.3272 \\
\hline Adjusted $R^{2}$ & 0.4141 & 0.4218 & 0.5338 & 0.5397 & 0.5404 \\
\hline
\end{tabular}

Notes: ${ }^{\star \star \star}$ Significant at $1 \%$ level, ${ }^{*}$ Significant at $5 \%$ level and *Significant at $10 \%$ level.

The estimated regressions equations obtained are given below:

$$
\begin{aligned}
& Y t d t a=0.0024+0.1276 * T A N G-1.2169 * R O A+0.0368 * S I Z E+0.0992 * R I S K+\varepsilon 1 \\
& \text { Ytdta }=-0.0798+0.1629 * \text { TANG }+0.0003 * L I Q-1.1685 * R O A+0.0409 * \text { SIZE }+ \\
& 0.1128 * \text { RISK }-0.5775 * N D T S H+\varepsilon 2 \\
& Y \text { tdta }=0.0426+0.1395 * T A N G+0.0005 * L I Q-1.2402 * R O A+0.0359 * \text { SIZE }+ \\
& 0.1140 * \text { RISK }-0.5140 * N D T S H+3.7768 * G D P-6.0884 * I N F+\varepsilon 3 \\
& Y \text { tdta }=-0.8564+0.1379 * \text { TANG }+0.0005 * L I Q-1.2402 * R O A+0.0354 * S I Z E+ \\
& 0.1142 * \text { RISK }-0.5125 * N D T S H+3.1977 * G D P+6.3173 * I N T+\varepsilon 4 \\
& Y \text { tdta }=-4.1665+0.1333 * \text { TANG }+0.0004 * L I Q-1.2456 * R O A+0.0350 * \text { SIZE }+ \\
& 0.1193 * R I S K-0.5142 * N D T S H+1.0303 * G D P+22.7398 * I N F+29.3272 * I N T+\varepsilon 5
\end{aligned}
$$

As we can see from model 5 because of the multicollinearity problem between GDP, INF and INT (identified by the VIF test) these variables results statistically insignificant. In fact GDP (model 3) and INT (model 4) have a positive and significant influence on TDTA. Otherwise INF (model 3) has a negative and significant influence on TDTA.

\section{Conclusions}

Capital Structure and the theories related to it are the primary subjects of research in corporate finance. This paper has attempted to find the determinants of capital structure of the Albanian firms. Six firm's specific variables namely tangibility, liquidity, profitability, size, risk and non- debt tax shields and three macroeconomic factors (GDP growth rate, inflation rate and prime lending rate) have been added as independent variables to measure their effect on firm's leverage.

Table5: A summary of this study results

\begin{tabular}{|c|c|}
\hline Variables & The relation with TDTA \\
\hline TANG & Positive \\
\hline LIQ & Positive \\
\hline ROA & Negative \\
\hline SIZE & Positive \\
\hline RISK & Positive \\
\hline
\end{tabular}




\begin{tabular}{|c|c|}
\hline NDTSH & Negative-not significant \\
\hline GDP & Positive \\
\hline INF & Negative \\
\hline INT & Positive \\
\hline
\end{tabular}

Table 5 shows the result of this study. So, GDP is positively related to capital structure. Several studies have provided empirical evidence on the positive relationship between GDP growth and leverage (Mateus, 2006; Saledi and Manesh, 2012). Inflation rate is negatively related to capital structure and interest rate is positively related to capital structure. Our results support the trade-off model which arguments that as interest rates increase the tax advantage of debt rises. This finding is not consistent with Antoniou et al. (2002) and Dincergok and Yalciner (2011) studies which proved that the interest rate is negatively related to leverage.

\section{References:}

Anderson, R.W. (2002).Capital structure, firm liquidity and growth.NBB working paper, no.27

Antoniou, A., Guney, Y. \& Paudyal, K. (2002). Determinants of corporate capital structure: Evidence from European countries. University of Durham, working paper.

Corcoran, P. (1977). Inflation, taxes and corporate investment incentives. Federal Reserve Bank of New York Quarterly Review, 2, 1-9.

Daskalakis, N., \& Psillaki, M. (2006). The determinants of capital structure of the SME's: Evidence from the Greek and the French firms, unpublished.

DeAngelo, H., \& Masulis, R.W. (1980) .Optimal capital structure under corporate and personal taxation. Journal of Financial Economics, 8, 3-29.

Degryse,H. P., Goeij P.,\& P. Kappert,P. (2009).The impact of firm and industry characteristics on small firms' capital structure: Evidence from Dutch panel data. European Banking Center Discussion, paper no. 2009-03.

Dincergok, B., \& Yalciner,K. (2011) . Capital structure decisions of manufacturing firms' in developing countries. Middle Eastern Finance and Economics, 12, 86-100.

Frank, Z., \&Goyal, V. (2003). Testing the pecking order theory of capital structure. Journal of Financial Economics, 67, 217-248.

Frank, M.Z., \& Goyal, V.K.(2009). Capital structure decisions: Which factors are reliably important? Financial Management, 38, 1-37.

Gujarati, N. (2004). Basic econometrics. New York: McGraw Hill Companies.

Gulati, D., \& Zantout, Z.(1997). Inflation, capital structure, and immunization of the firm's growth potential. Journal Of Financial And Strategic Decisions, $10: 1,77-90$.

Gurcharan, S. (2010). A Review of optimal capital structure determinant of selected ASEAN countries. International Research Journal of Finance and Economic , 47,30-41.

Mateus, C. (2006). Taxes and corporate debt policy: Evidence from unlisted firms of sixteen European countries. The Aarhus School of Business, Denmark. unpublished.

Maryam Paydar,M.,\& Bardai,B.(2012). Leverage behavior of Malaysian manufacturing companies a case observation of the industrial sector's companies in bursa Malaysia. International Research Journal of Finance and Economics, 90, 54-65.

Mutenheri, E .,\& Green, C.J. (2002). Financial return and financing decisions of listed firms in Zimbabwe. Economic Research Paper. No.0215. Department of Economics, Loughborough University.

Myers, S. (1984). The capital structure puzzle. Journal of Finance, 39, 575-92.

Opler, T., Pinkowitz, L., Stulz, R., \& Williamson, R. (1999).The determinants and implications of corporate cash holdings. Journal of Financial Economics, 52, 3-46.

Rajan, G., \& Zingales, L. (1995). What do we know about capital structure? Some evidence from international data. Journal of Finance, $50,1421-1460$.

Republic of Albania, Ministry of Energy, Transport and Economy (2007). Programi strategjik per zhvillimin e SME-ve per periudhen 20072009.

Saddour, K. (2006). The determinants and the value of cash holdings: Evidence from French firms.CEREG,1-33.Available: http://www.dauphine.fr/cereg/cahiers_rech/cereg200606.pdf

Salehi,M.,\& Manesh,N.B.(2012). A study of the roles of firm and country on specific determinates in capital structure: Iranian evidence. International Management Review , $8: 2,51-62$.

Shahjahanpour, A., Ghalambor, H. \& Aflatooni A.(2010).The determinants of capital structure choice in the Iranian companies. International Research Journal of Finance and Economics,56,167-178.

Titman, S., \& Wessels, R. (1988). The determinants of capital structure choice. Journal of Finance, 43, 1-19.

$\mathrm{Xu}, \mathrm{J}$. (2012). Profitability and Capital structure: Evidence from import penetration. Journal of Financial Economies, 106,427-446. 